\title{
Хлорирование в солевом расплаве в технологии производства поликристаллического кремния
}

\author{
В. Иванов ${ }^{1}$
}

УДК 548.522:621.315.592 | ВАК 05.27.06

\begin{abstract}
Решение проблемы рентабельности производства поликристаллического кремния является важнейшим фактором развития современной электроники. Для снижения себестоимости поликремния предлагается в качестве исходного сырья использовать материалы, содержащие диоксид кремния. Эти материалы подвергать хлорированию, а образующийся тетрахлорид кремния гидрировать до трихлорсилана, используемого при водородном восстановлении кремния. Литературные данные по хлорированию кремнезема показывают принципиальную возможность хлорирования $\mathrm{SiO}_{2}$ в расплаве солей. Описаны технологические особенности данного процесса, параметры, влияющие на хлорирование диоксида кремния, применяющиеся в процессе сырьевые материалы. Определены удельные расходы основных сырьевых материалов и их стоимость в традиционной технологии производства поликремния, применявшейся в отечественной промышленности, и предлагаемой новой технологии.

Сделан вывод, что переход с традиционной на новую технологию производства поликристаллического кремния поможет значительно снизить затраты на сырье, что даст возможность решить задачу по созданию конкурентоспособного производства полупроводникового кремния.
\end{abstract}

\section{ВВЕДЕНИЕ}

В настоящее время отрасль полупроводникового кремния находится в сложных условиях, определенных, с одной стороны, необходимостью продолжения развития солнечной энергетики и электронной промышленности, на которой базируются информационные технологии, с другой стороны - последствиями мирового экономического кризиса 2008 года.

Ускоренное развитие фотовольтаики в начале века привело к резкому росту цены на поликристаллический кремний (ПКК), вследствие этого в 2008-2009 годах был реализован ряд проектов по повышению производительности действующих предприятий и строительству новых заводов. Мощность всех действующих производителей по состоянию на 2013-2014 годы составила 280 тыс. т ПКК [1]. Экономический кризис привел к значительному перепроизводству поликремния на мировом рынке, вслед за которым последовало резкое падение цен на этот материал: в 2014 году средние цены на ПКК составляли -25 долл. / кг, в 2015 году - 15 долл. / кг. Вследствие снижения рентабельности в 2011-2013 годах многие

ООО «Германий и приложения», v.m.ivanov@rambler.ru. компании перестали функционировать, а оставшиеся снизили объемы производства. По мнению аналитиков, существующие мощности используются на 45-50\% [1] Единственный в России завод по производству поликремния, ООО «Усолье-Сибирский силикон», был закрыт.

Эксперты в области полупроводниковых материалов считают [2], что одним из путей успешного развития отрасли является снижение себестоимости производства поликристаллического кремния, являющегося базовым материалом для электроники и солнечной энергетики. Решение этой задачи возможно путем разработки технологий с пониженными производственными затратами и совершенствованием процессов, используемых для получения поликремния.

\section{МЕТОДЫ И МАТЕРИАЛЫ ДЛЯ ПОЛУЧЕНИЯ ПОЛИКРИСТАЛЛИЧЕСКОГО КРЕМНИЯ}

В настоящее время основная доля ПКК производится по технологической схеме Сименс-процесса [2, 3], включающей получение трихлорсилана (ТXC), его очистку и водородное восстановление в реакторах стержневого типа. Такая технологическая схема была реализована на Запорожском титано-магниевом комбинате [4]. Схема включала: 
прямой синтез хлористого водорода; гидрохлорирование технического кремния; конденсацию хлорсиланов; выделение и очистку трихлорсилана, его водородное восстановление с получением поликремния; выделение из отходящей парогазовой смеси водорода и трихлорсилана, а также их рециклы на переделе водородного восстановления. При этом образовывался ряд попутных продуктов, которые выводились из технологической схемы. Фактически эти продукты представляли собой безвозвратные потери, снижающие технико-экономические показатели производства, что вело к повышению себестоимости поликремния.

При синтезе трихлорсилана гидрохлорированием технического кремния, в реакторах с псевдоожиженным слоем образуется значительное количество мелкодисперсной (<0,1 мм) кремниевой пыли. Поскольку использовать эту кремниевую пыль в производстве ПКК в типовом реакторе гидрохлорирования невозможно, ее приходится захоранивать на полигоне промышленных отходов, что приводит к снижению выхода кремния в готовый продукт и к увеличению производственных расходов.

Особенностью Сименс-процесса является то, что в качестве побочного продукта образуется значительное количество тетрахлорида кремния (ТК) - до 15 т на 1 т ПКК. Для повышения рентабельности на производящих поликремний предприятиях используют различные варианты утилизации ТК. Его реализуют в качестве сырья для производства кварцевых изделий, оптического волокна, аэросила, так называемой белой сажи, кремнийорганических материалов. На передовых предприятиях применяют процесс гидрирования тетрахлорида кремния до трихлорсилана, позволяющий повысить извлечение кремния в готовую продукцию и снизить его безвозвратные потери. В промышленности применяются методы высокотемпературного гидрирования и каталитического гидрирования, причем последний имеет значительно меньшую энергоемкость и рассматривается как наиболее перспективный метод, что учитывается при проектировании и строительстве новых предприятий [5].

Анализ производственных затрат показал, что значительную долю в себестоимости ТХС (до 74\%) занимают сырьевые материалы: технический кремний, водород, хлор. В стоимости сырьевых материалов доля технического кремния составляет 75\%, что объясняется его высокой ценой. Технический кремний получают карботермическим восстановлением кварцитов в дуговой электрической печи при температуре свыше $2000^{\circ} \mathrm{C}$. Данный процесс связан с высокими технологическими и энергетическими затратами, в том числе на производство восстановительных материалов и на приготовление шихты, когда все исходные материалы дробят, а мелкую фракцию отбрасывают. Кроме того, во время выплавки кремния происходит выделение различных газов и мелкой пыли компонентов шихты. Вследствие этого в настоящее время на мировом рынке цена технического кремния составляет 2210 долл. за т. На рынке России эта цена доходит до 240000 руб. / т.

В настоящее время в научно-технической литературе $[2,6,7]$ предлагается вместо технического кремния в качестве сырьевого материала использовать специально подготовленный кварцевый песок и техногенные отходы абразивной и электродной промышленности, содержащие диоксид и карбид кремния. В процессе производства эти материалы предлагается смешивать с восстановителем, затем осуществлять высокоэнергетическую обработку смеси, после чего подвергать прямому хлорированию в шахтном хлораторе. Образующийся тетрахлорид кремния конвертировать низкотемпературным гидрированием в трихлорсилан, который используется для получения ПКК водородным восстановлением. Специальная процедура улавливания водой хлористого водорода на выходе реакторов водородного восстановления с использованием автоматизированного автономного модуля разложения соляной кислоты на хлор и водород позволят снизить производственные затраты. В новой технологической схеме сохраняется принцип замкнутости по хлору, водороду, воде, хлористому водороду. Оценки экономической эффективности новой технологии определяются возможностью снижения себестоимости поликристаллического кремния до 12...10 долл. за кг.

Ранее в литературе отмечалось [8], что для промышленного производства тетрахлорида кремния природное окисное сырье не нашло широкого применения, несмотря на многочисленные исследования в этом направлении. Были проведены работы [9] по изучению влияния температуры и химической активности на скорость хлорирования и степень извлечения $\mathrm{SiO}_{2}$ из различных кремнеземов. В присутствии угля температура начала хлорирования аморфного кремнезема - 730-740 ${ }^{\circ} \mathrm{C}$, кварца $-1220^{\circ} \mathrm{C}$. Степень хлорирования в смеси с углем $(1: 1)$ при 1100-1150 С в течение 1 ч составляет для песка 1,62\%, плавленого кварца 15,2\%, аморфного кремнезема 40,56\%. Реакция аморфного $\mathrm{SiO}_{2}$ с хлором в присутствии угля в интервале 850-1000 С замедляется, а затем снова резко ускоряется, что объясняется превращением аморфной кремниевой кислоты в кристобалит. Установлена также зависимость между плотностью кремнезема и степенью его хлорируемости.

Из всех видов природного сырья наибольший интерес для производства тетрахлорида кремния представляют диатомит и трепел, так как они являются аморфной разновидностью кремнезема и обладают хорошо развитой поверхностью.

Предложен [10] способ получения четыреххлористого кремния в расплаве хлоридов щелочных и щелочноземельных металлов. Способ позволяет проводить процесс 
хлорирования при температуре 700-800 C. Смесь молотых диатомита и древесного угля в соотношении 1,7:1 хлорируют в течение 5 ч. Реакционные газы охлаждают до минус $20-22{ }^{\circ} \mathrm{C}$, получая сырьевой $\mathrm{SiCl}_{4}$. О выходе кремния в продукт авторы не сообщают.

Установлено [8] вредное влияние на скорость хлорирования накапливающихся в расплаве хлоридов щелочноземельных металлов, в особенности хлоридов магния. При хлорировании диатомита в расплаве солей на установке производительностью 1 т / сутки $\mathrm{SiCl}_{4}$ наблюдался унос до 30\% диатомита вследствие плохой смачиваемости его расплавом. При добавлении в расплав 5-10\% хлористого алюминия унос диатомита уменьшается.

Авторы патента [11] хлорировали аморфный диоксид кремния в расплаве, применяя лабораторный реактор. В качестве сырья использовался остаток от выщелачивания серпентинита состава $\mathrm{SiO}_{2}-89,2$ вес. \%, $\mathrm{H}_{2} \mathrm{O}-$ 6,7 вес. \%, сумма MgO, FeO, $\mathrm{Al}_{2} \mathrm{O}_{3} \sim 4,1$ вес. \%, измельчен-

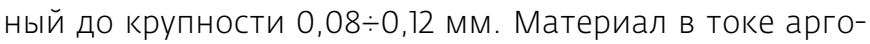
на прогревался в течение часа при температуре $650{ }^{\circ} \mathrm{C}$, в результате чего содержание влаги было снижено до 1,48 вес.\%. В качестве углеродного восстановителя применялся березовый уголь марки «А» крупностью 0,10,14 мм. Для приготовления расплава использовали хлориды калия и натрия, взятые в мольном соотношении 1: 1. Данная смесь имеет температуру плавления $710^{\circ} \mathrm{C}$. При температуре процесса 850-900 С расплав имеет хорошую подвижность, что поддерживает устойчивую работу ванны. Рабочая температура обеспечивалась нагревом электропроводящего соляного расплава при пропускании через него переменного тока. С этой целью реактор был оснащен электродами. Для обеспечения постоянной концентрации реагентов в расплаве в реактор мелкими порциями загружалась подготовленная шихта с весовым соотношением $\mathrm{SiO}_{2}: \mathrm{C}=1$ : 0,27. Это позволило поддерживать содержание диоксида кремния в пределах 1-3\%, углерода 3-5\%. Хлор подавался с расходом, обеспечивающим максимальное использование хлора и хорошую циркуляцию расплава в ванне. Выходящая из реактора парогазовая смесь, содержащая $\mathrm{SiCl}_{4}, \mathrm{AlCl}_{3}, \mathrm{FeCl}_{3}, \mathrm{CO}_{2}$ и CO, поступала в аппараты улавливания хлоридов металлов, после чего тетрахлорид кремния конденсировался при температуре минус $35^{\circ} \mathrm{C}$. За 42 ч эксперимента было получено 5120 г тетрахлорида кремния. Извлечение кремния в продукт составило 94,5\%. Слито 7120г расплава из реактора, о составе расплава не сообщается.

Эксперимент показал принципиальную возможность хлорирования аморфного диоксида кремния в расплаве. следует отметить, что остаток от выщелачивания серпентинита получается при переработке промышленных отвалов, которые локализованы в месте расположения предприятия. Для разработки новой технологии производства поликристаллического кремния целесообразно использовать более широкий ряд сырьевых материалов, содержащих диоксид кремния, таких как кварциты, кварцевый песок или другие природные материалы.

Информации о проводимых за рубежом исследованиях по хлорированию кремнезема в расплаве солей у автора нет. В период бурного развития солнечной энергетики, когда цена на поликремний доходила до 400 долл./кг [12], производители поликристаллического кремния активно наращивали мощности производств, а инвесторы вкладывали средства в строительство новых предприятий. Поскольку Сименс-процесс был наиболее изученным и освоенным способом промышленного производства ПКК, новые заводы запускались с использованием этого способа. В результате, в настоящее время 88\% поликремния в мире производится по методу Сименс-процесса [12].

В условиях перепроизводства ПКК и его низкой цены на мировом рынке развивать новые способы получения поликремния зарубежные инвесторы, по-видимому, считают преждевременным.

\section{ТЕХНОЛОГИЧЕСКИЕ ОСОБЕННОСТИ ХЛОРИРОВАНИЯ В СОЛЕВОМ РАСПЛАВЕ}

На примере из практики современной промышленности предлагается рассмотреть технологические особенности процесса хлорирования в солевом расплаве. Известно, что в производстве губчатого титана [13], при рудотермической электроплавке ильменитового концентрата, в титановый шлак попадает некоторое количество диоксида кремния. Соответственно, прихлорировании титанового шлака вместе с диоксидом титана хлорируется и диоксид кремния с образованием тетрахлорида кремния по реакциям:

$$
\begin{aligned}
& \mathrm{SiO}_{2}+\mathrm{C}+2 \mathrm{Cl}_{2}=\mathrm{SiCl}_{4}+\mathrm{CO}_{2} \\
& \mathrm{SiO}_{2}+2 \mathrm{C}+2 \mathrm{Cl}_{2}=\mathrm{SiCl}_{4}+2 \mathrm{CO}
\end{aligned}
$$

В настоящее время в титановой промышленности широкое распространение получил метод хлорирования измельченной шихты в расплавехлоридов щелочных металлов. Метод обладает следующими преимуществами:

- интенсивный барботаж вводимого хлора обеспечивает эффективный тепло- и массообмен, высокую удельную производительность;

- подачей хлора и отводом избыточного тепла возможно обеспечить терморегулирование процесса;

- при организации процесса предъявляются менее жесткие требования к сырью по содержанию примесей алюминия, железа, кальция;

- поскольку значительная часть хлоридов примесей растворяется в расплаве, выходящий из хлоратора 
целевой продукт меньше загрязняется примесями алюминия, железа, кальция, что облегчает его последующую очистку;

- процесс хлорирования в расплаве идет преимущественно с образованием СО $_{2}$, это исключает образование взрывоопасных газовых смесей, что упрощает условия эксплуатации оборудования.

Схематичное изображение реактора для процесса хлорирования металлосодержащего сырья в солевом расплаве представлено на рис. 1.

При хлорировании в расплаве солей, частицы шихты находятся во взвешенном состоянии равномерно по всему объему расплава. Подаваемый в нижнюю зону расплава под углом к подине при давлении 170 кПа хлор диспергируется на мелкие пузырьки, которые собираются на поверхности углерода, и затем взаимодействует с оксидами, что способствует непрерывному барботажу расплава. Выделяющийся углекислый газ усиливает барботаж. Уровень расплава в хлораторе должен быть таким, чтобы хлор полностью прореагировал в объеме расплава.

Непрерывный отвод избыточного тепла, периодический вывод с отработанным расплавом примесей и непрохлорированных компонентов позволяют интенсифицировать процесс и обеспечить непрерывную и равномерную работу хлоратора.

\section{ХЛОРИРОВАНИЕ КРЕМНЕЗЕМА И ФАКТОРЫ, ВЛИЯЮЩИЕ НА ПРОЦЕСС}

Практика производства тетрахлорида титана хлорированием в расплаве показывает, что метод является пригодным для получения тетрахлорида кремния из оксидов кремния. При этом следует учитывать, что оксиды металлов имеют разную склонность кхлорированию: по этому признаку их можно расположить в следующий ряд [13]:

$\mathrm{K}_{2} \mathrm{O} \rightarrow \mathrm{Na}_{2} \mathrm{O} \rightarrow \mathrm{CaO} \rightarrow \mathrm{MnO} \rightarrow \mathrm{FeO} \rightarrow \mathrm{MgO} \rightarrow \mathrm{TiO}_{2} \rightarrow \mathrm{Al}_{2} \mathrm{O}_{3} \rightarrow \mathrm{SiO}_{2}$

Из этого ряда следует, что присутствующие в сырьевых материалах примеси будут хлорироваться и переходить в расплав. Некоторые из примесей играют активную роль в процессе хлорирования кремнезема, что следует учитывать при выборе исходных материалов для производства тетрахлорида кремния.

Для процесса хлорирования важна роль восстановителя, в качестве которого применяется пековый кокс. Согласно существующей теории [13], в процессе хлорирования оксидов углерод выполняет каталитическую и восстановительную функции. На первом этапе углерод сорбирует на своей поверхности хлор, при этом молекулыхлора диссоциируют на атомы:

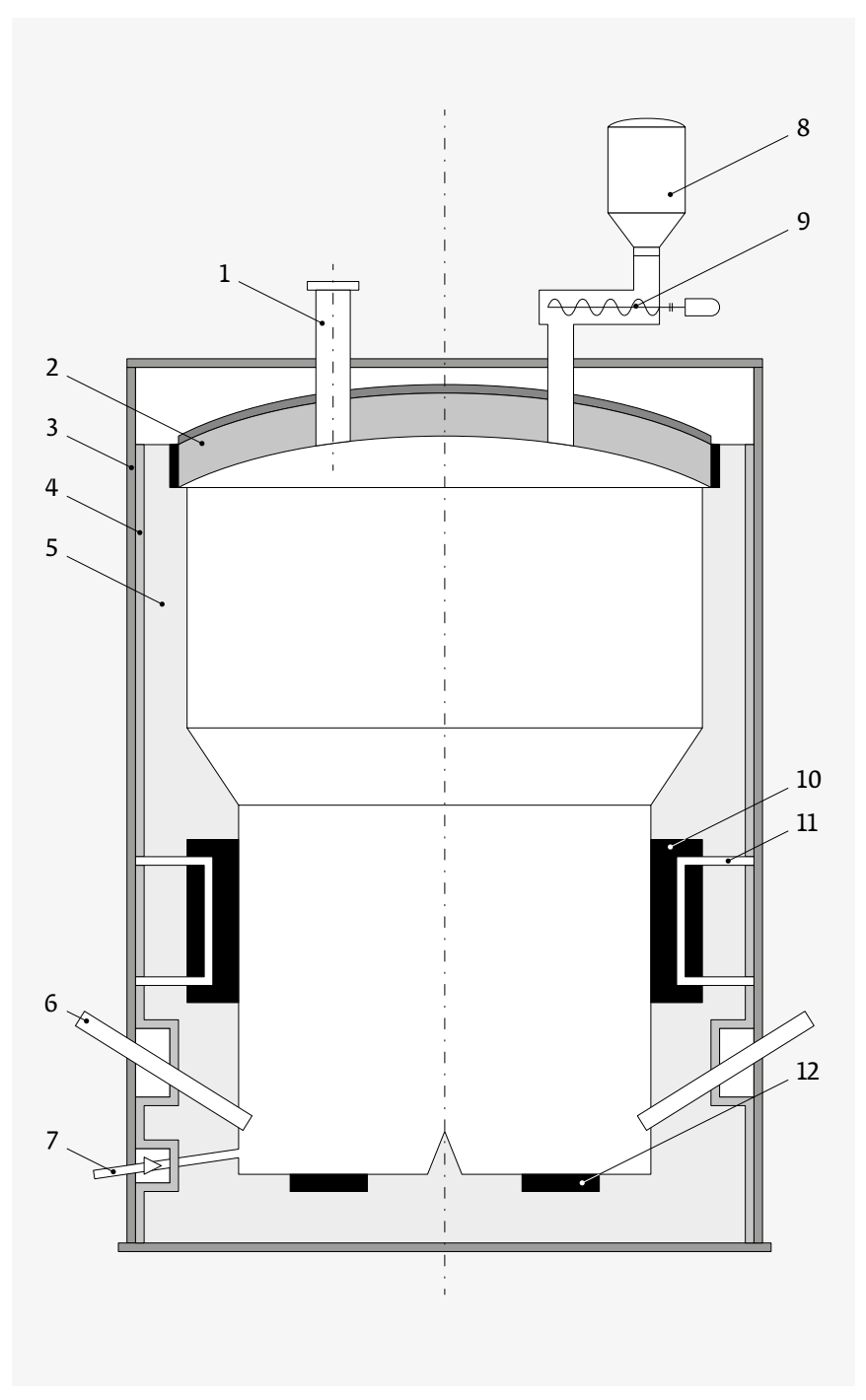

Рис. 1. Схема солевого хлоратора: 1 - газоход, 2 - свод, 3 - кожух, 4 - графито-антраценовый слой, 5 - шамотная футеровка, 6 - фурма, 7 - нижний слив расплава, 8 - шихтовый бункер, 9 - шнековый питатель, 10 - графитовый электрод, 11 - водоохлаждаемая штанга, 12 - донные графитовые электроды

На втором этапе углерод выполняет роль транспортера хлора и катализатора. Химически более активный хлор вступает во взаимодействие с окислом металла:

$$
\mathrm{MeO}+\mathrm{C}+2 \mathrm{Cl}=\mathrm{MeCl}_{2}+\mathrm{O}+\mathrm{C}
$$

При этом в результате реакции атомарного хлора с оксидом металла образуется атомарный кислород.

На третьем этапе углерод выполняет роль восстановителя - восстанавливает кислород с образованием, в основном, двуокиси углерода:

$$
\mathrm{C}+\mathrm{Cl}_{2} \rightarrow \mathrm{C}+2 \mathrm{Cl}
$$

$\mathrm{2O}+\mathrm{C}=\mathrm{CO}_{2}$ 
При производстве технического кремния в качестве восстановителя используется древесный уголь, который имеет высокие реакционную способность, УЭС и пористость - важные качества при рудовосстановительной плавке кремния. Однако при хлорировании кремнезема в расплаве солей эти качества не имеют столь большого значения, тем более, что по литературным данным [14] 77,4\% фосфора и 51,9\% бора в технический кремний попадают именно из древесного угля. Поскольку фосфор и бор трудно отделяются от кремнийсодержащих материалов при химической и металлургической очистке, то их уменьшение в сырьевых материалах приведет к повышению качества ПкК.

Прихлорировании в расплаве большее значение имеют физические свойства углерода: плотность и смачиваемость расплавом. Необходимыми свойствами обладают нефтяной и пековый коксы, имеющие незначительное содержание фосфора. Согласно имеющимся данным [8], качество пекового кокса значительно выше качества нефтяного кокса. Поэтому при хлорировании кремнийсодержащего сырья в качестве углеродистого восстановителя целесообразно использовать пековый кокс.

Содержание углерода в расплаве должно быть в интервале 2-5\%. При его содержании меньше 2\% процесс хлорирования ухудшается из-за дефицита восстановителя. При содержании кокса более 5\% повышается вязкость и снижается подвижность расплава, что ухудшает свойства расплава как среды хлорирования.

На скорость хлорирования оказывает влияние величина поверхности сырья и восстановителя. Поэтому перед подачей в хлоратор кремнийсодержащее сырье и восстановитель необходимо измельчать до крупности $\leq 0,16$ мм и высушивать до содержания влаги <1\% [13]. Показатель твердости по шкале Мооса для кварца равен 7, что позволяет использовать стандартное размольное оборудование, такое как шаровые мельницы. Пековый кокс обычно дробят на молотковых или двухвалковых дробилках и измельчают в шаровых мельницах до крупности не более 0,16 мм.

Солевой расплав является не только средой для хлорирования, но и универсальным катализатором, повышающим концентрацию атомарного хлора в зоне реакции, поэтому его природа имеет большое значение. В процессе активную роль играют расплавленные соли щелочных и щелочноземельных элементов, хлориды алюминия и железа. Значительное влияние на скорость хлорирования оказывает присутствие легкохлорируемых примесей железа и алюминия, увеличивающих скорость хлорирования в несколько раз.

Железо образует хлориды двух степеней окисления: хлорное железо $\left(\mathrm{FeCl}_{3}\right)$ и хлористое железо $\left(\mathrm{FeCl}_{2}\right)$. В солевом расплаве $\mathrm{FeCl}_{2}$ химически связывает подаваемый в расплав хлор, переходя при этом в $\mathrm{FeCl}_{3}$. Хлорное железо отдает атом хлора взвешенному в расплаве оксиду металла, образуя соответствующий хлорид и вновь превращаясь при этом в хлористое железо.

При этом процесс проходит через две чередующиеся стадии - стадию окисления хлористого железа хлором и стадию восстановления хлорного железа металлом:

$$
\begin{gathered}
2 \mathrm{FeCl}_{2}+\mathrm{Cl}_{2}=2 \mathrm{FeCl}_{3}, \\
2 \mathrm{MeO}+4 \mathrm{FeCl}_{3}+\mathrm{C}=2 \mathrm{MeCl}_{2}+4 \mathrm{FeCl}_{2}+\mathrm{CO}_{2},
\end{gathered}
$$

где Ме - металл

Первая стадия процесса представляет собой химическое связывание газообразного хлора жидкостью. Эта реакция, проходящая на границе жидкой и газовой фаз, типичный пример хемосорбции и может рассматриваться как процесс массопередачи при абсорбции, сопровождающейся химической реакцией.

Образовавшийся на стадии восстановления дихлорид железа реагирует с хлором с образованием хлорного железа, после чего процесс повторяется. Таким образом, хлорное железо выполняет функцию катализатора процесса и переносчика хлора к оксиду металла. Аналогичным образом каталитическим действием обладают соединения марганца и хрома.

Кремний взаимодействует с хлором в расплаве, содержащем переносчик хлора, с большей эффективностью, чем в расплаве чистых хлоридов щелочных и щелочноземельных металлов. Если хлориды железа постоянно присутствуют в расплаве и не удаляются в процессе хлорирования, наличие железа в исходном сырье необязательно.

Кроме того, солевой расплав обеспечивает получение более качественного целевого продукта. Образующиеся при хлорировании хлориды железа и алюминия связываются схлоридами калия и натрия, образуя комплексные соединения типа $\mathrm{KFeCl}_{4}, \mathrm{NaAlCl}_{4}$, которые в дальнейшем выводятся с отработанным расплавом. Вследствие этого облегчается последующая очистка целевого продукта.

Хлор в расплаве обладает незначительной растворимостью, это обстоятельство лимитирует стадию сорбции хлора на поверхности углерода. Соединения железа, алюминия, марганца и хрома, реагируя схлором, переходят в хорошо растворимые в расплаве хлориды, являющиеся хорошими хлорирующими агентами

Значительное влияние на скорость процесса хлорирования оказывает состав расплава. В расплавах солей $\mathrm{KCl}, \mathrm{NaCl}, \mathrm{CaCl}_{2}, \mathrm{MgCl}_{2}$ хлорирование протекает неодинаково. Различная интенсивность хлорирования объясняется способностью этиххлоридов к образованию в расплаве комплексных соединений с продуктами реакции. Кроме того, скорость хлорирования оксидов зависит от поверхностного натяжения и вязкости расплава, а также 
от смачиваемости хлорируемых материалов и типа восстановителя. Из данных солей наименьшая скорость хлорирования в расплаве $\mathrm{CaCl}_{2}$, а наибольшая - в расплавах $\mathrm{KCl}$ и $\mathrm{NaCl}$. Поэтому рекомендуется [8] запускать хлоратор в работу на эквимолярной смеси хлоридов натрия и калия, что позволяет снизить температуру кристаллизации исходного плава, а также уменьшить его вязкость. Для сокращения пускового периода и устранения проскоков хлора рекомендуется вносить в плав затравкухлорного железа (5-7\% от количества хлоридов щелочных металлов).

Физические свойства расплава зависят от количества нерастворимых в расплаве материалов. Оксиды металлов незначительно растворяются в расплавехлоридов, углеродистые восстановители растворяются еще меньше. На отечественных предприятиях, эксплуатирующихсолевые хлораторы, концентрацию хлорируемого оксида металла поддерживают в интервале 1,5-5\%. При снижении концентрации меньше 1\% возрастает скорость хлорирования других оксидов и хлоридов, что снижает скорость целевой реакции. Превышение концентрации более 5\% ведет к ухудшению физических свойств расплава. Таким образом, для обеспечения максимальной скорости хлорирования диоксида кремния необходимо выбрать оптимальный состав солевого расплава, как по соотношению хлоридов щелочных металлов, так и по концентрации компонентов шихты и примесных соединений.

Определяющее значение для процесса хлорирования имеет температура расплава. Повышение температуры ведет к возрастанию скорости хлорирования окислов примесей, хлориды и оксохлориды которых попадают в систему конденсации и загрязняют тетрахлорид кремния, затрудняя его последующую очистку. Оптимизирование температуры позволит замедлить процесс хлорирования примесей, которые будут выводиться с отработанным расплавом.

Большое значение для процесса хлорирования имеет чистота хлора. Содержащиеся в хлоре примеси разбавляют парогазовую смесь и ухудшают процесс конденсации тетрахлорида кремния. Наиболее отрицательное влияние оказывает кислород, который может вступать во взаимодействие с тетрахлоридом кремния по реакции [15]:

$$
2 \mathrm{SiCl}_{4}+1 / 2 \mathrm{O}_{2}=\mathrm{Si}_{2} \mathrm{OCl}_{6}+\mathrm{Cl}_{2}
$$

Образующийся гексахлордисилоксан конденсируется вместе с тетрахлоридом кремния, загрязняя его. Кроме того, кислород реагирует с углеродом, образуя углекислый газ, который разбавляет парогазовую смесь и снижает парциальное давление тетрахлорида кремния. Следовательно, для производства тетрахлорида кремния методом хлорирования в расплаве хлоридов щелочных металлов нужно использовать хлор с минимальным содержанием примесей, например, высшего сорта по ГОСТ 6718-93.

Влияние давления на скорость процесса хлорирования в технической литературе не отмечено. Согласно данным, представленным в работе [13] , давление под сводом хлоратора регулируется в интервале -1470 ...+1470 Па $(-150 \ldots+150$ мм вод. ст.). В практике промышленного производства давление парогазовой смеси на выходе из хлоратора поддерживают на уровне \pm 2942 Па ( \pm 300 мм вод. ст.), что, по-видимому, способствует лучшему растворению хлора.

Технологические особенности хлорирования диоксида кремния в солевом расплаве необходимо учитывать при проектировании солевого хлоратора и при освоении промышленного производства тетрахлорида кремния из кремнезема.

\section{ОЦЕНКА ЗАТРАТ НА СЫРЬЕВЫЕ МАТЕРИАЛЫ ДЛЯ ТРАДИЦИОННОЙ И НОВОЙ ТЕХНОЛОГИЙ ПРОИЗВОДСТВА ПКК}

На основе имеющихся данных по расходу сырьевых материалов определены стоимость сырья в традиционной технологии производства поликремния, применявшейся в отечественной промышленности, и новой технологии, основанной на хлорировании диоксида кремния в расплаве солей с гидрированием образующегося тетрахлорида кремния до трихлорсилана. ТК, образующийся при получении ПКК в процессе водородного восстановления, также гидрированием конвертируется в трихлорсилан.

Значительную долю стоимости в традиционной технологии занимает водород, поэтому в новой технологии необходимо использовать установку низкотемпературной регенерации компании Chemical Design, Inc. или блоки конденсации хлорсиланов и регенерации водорода производства АО «Красмаш», позволяющие разделять водород, хлористый водород и хлорсиланы, которые можно рециркулировать в технологической схеме. Такая технологическая схема позволяет снизить затраты на водород.

В табл. 1 представлены удельные расходы основных сырьевых материалов и их стоимость для традиционной и новой технологических схем производства ПКК. Цены на сырьевые материалы взяты на сайтах поставщиков. расходы материалов по новой технологии получены расчетным путем на основе практики работы промышленных солевых хлораторов.

\section{ЗАКЛЮЧЕНИЕ}

Сравнительный анализ расчетных значений позволяет сделать вывод о том, что переход с традиционной на новую технологию производства поликристаллического кремния может дать снижение затрат на сырье в 8,7 раз. 
Таблица 1. Расходы и стоимость материалов

\begin{tabular}{|c|c|c|c|c|}
\hline Сырьевые материалы & Расход на 1 кг ПКК & Цена & $\begin{array}{r}\text { Стоимость, } \\
\text { руб. }\end{array}$ & $\begin{array}{r}\text { Суммарная } \\
\text { стоимость } \\
\text { материалов, } \\
\text { руб. }\end{array}$ \\
\hline \multicolumn{5}{|c|}{ Традиционная технология } \\
\hline Кремний & $5,788 \mathrm{k \Gamma}$ & 140000 руб./т & 810,32 & \multirow[t]{3}{*}{4566,26} \\
\hline Хлор & $20,907 \mathrm{kr}$ & 21599,6 руб. / т & 451,58 & \\
\hline Водород & $29,139 \mathrm{M}^{3}$ & 113,40 руб. / M $^{3}$ & 3304,36 & \\
\hline \multicolumn{5}{|l|}{ Новая технология } \\
\hline Кремнезем & $5,6914 \mathrm{Kr}$ & 2200 руб. / т & 12,52 & \multirow[t]{7}{*}{521,69} \\
\hline Хлор & $9,928 \mathrm{K \Gamma}$ & 21599,6 руб. / т & 214,44 & \\
\hline Водород & $2,480 \mathrm{M}^{3}$ & 113,40 руб. / $\mathrm{M}^{3}$ & 281,23 & \\
\hline KoKc & $1,544 \mathrm{kr}$ & 2500 руб. / т & 3,86 & \\
\hline Карналлит & $0,0114 \mathrm{~K} \Gamma$ & 4892 руб. / т & 0,06 & \\
\hline Хлористый калий & $0,665 \mathrm{kr}$ & 11412 руб. / т & 7,59 & \\
\hline Хлористый натрий & $0,662 \mathrm{k \Gamma}$ & 3000 руб. / т & 1,99 & \\
\hline
\end{tabular}

Снижение производственных затрат в сочетании с использованием современного оборудования и цифровых систем управления технологическими процессами даст возможность решить задачу по созданию конкурентоспособного производства полупроводникового кремния.

\section{ЛИТЕРАТУРА}

1. Некрасов А. В., Наумов А. В. Перспективы рынка поликристаллического кремния // Известия вузов. Материалы электронной техники. 2014. Т. 17. №4. С. 233-239.

2. Критская Т.В., Шварцман Л. Я. Современные технологии получения кремния полупроводниковой чистоты // Тезисы докладов ХІ Конференции “Кремний-2016». - Новосибирск, 2016. С. 21.

3. Грибов Б.Г., Котков А. П. Проблемы получения и области применения высокоомного кремния и наночастиц кремния // Тезисы докладов X Конференции “Кремний-2014". - Иркутск, 2014. С. 8.

4. Иванов В. М., Трубицын Ю. В. Перспективы создания замкнутого производства поликристаллического кремния // Нові технології. 2010. № 1. С. 53-58.

5. Иванов В.М., Трубицин Ю. В. Актуальность гидрирования тетрахлорида кремния в технологии полупроводникового кремния // Тезисы докладов VII Международной конференции «Кремний-2010». - Нижний Новгород, 2010. С. 62.

6. Международная заявка WO 2015/199636 Al. Способ получения поликристаллического кремния / Шварцман Л.Я.,
Прутцков Д. В., Додонов В. Н.; заявл. 23.06.2014; опубл. 30.12.2015.

7. Критская Т. В., Шварцман л. Я. Новая промышленная технология получения поликристаллического кремния "Кремний из песка" // Тезисы докладов XII Международной конференции "Кремний-2018". Черноголовка, 2018. С. 8.

8. Фурман А.А., Рабовский Б.Г. Основы химии и технологии безводных хлоридов. - М.: Химия, 1970. 256 с.

9. Фурман А.А. Неорганические хлориды. - М.: Химия, 1980. C. 190.

10. А. С. 211524 СССР. Способ непрерывного получения четыреххлористого кремния / Фурман А. А., Мичкова 3.И.; заявл. 15.06.1956; опубл. 19.11.1968.

11. Пат. 2450969 РФ. Способ производства тетрахлорсилана / Щелконогов А. А., Щелконогов М. А., Мальцев Н. А., Мальцев А. Н.; заявл. 8.11.2010; опубл. 20.05.2012.

12. Наумов А. В. Рынок поликристаллического кремния: состояние и перспективы // Электроника. 2015. № 9. C. 94-101.

13. Байбеков М. К., Попов В.Д., Чепрасов И. М. Производство четыреххлористого титана. - М.: Металлургия, 1987. С. 12.

14. Фалькевич э.С. и др. Технология полупроводникового кремния. - М.: Металлургия, 1992. С. 146.

15. Лапидус И. И., Нисельсон Л. А. Тетрахлорсилан и трихлорсилан. - М.: Химия, 1970. С. 13. 


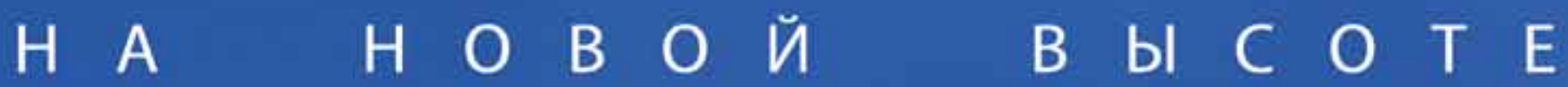

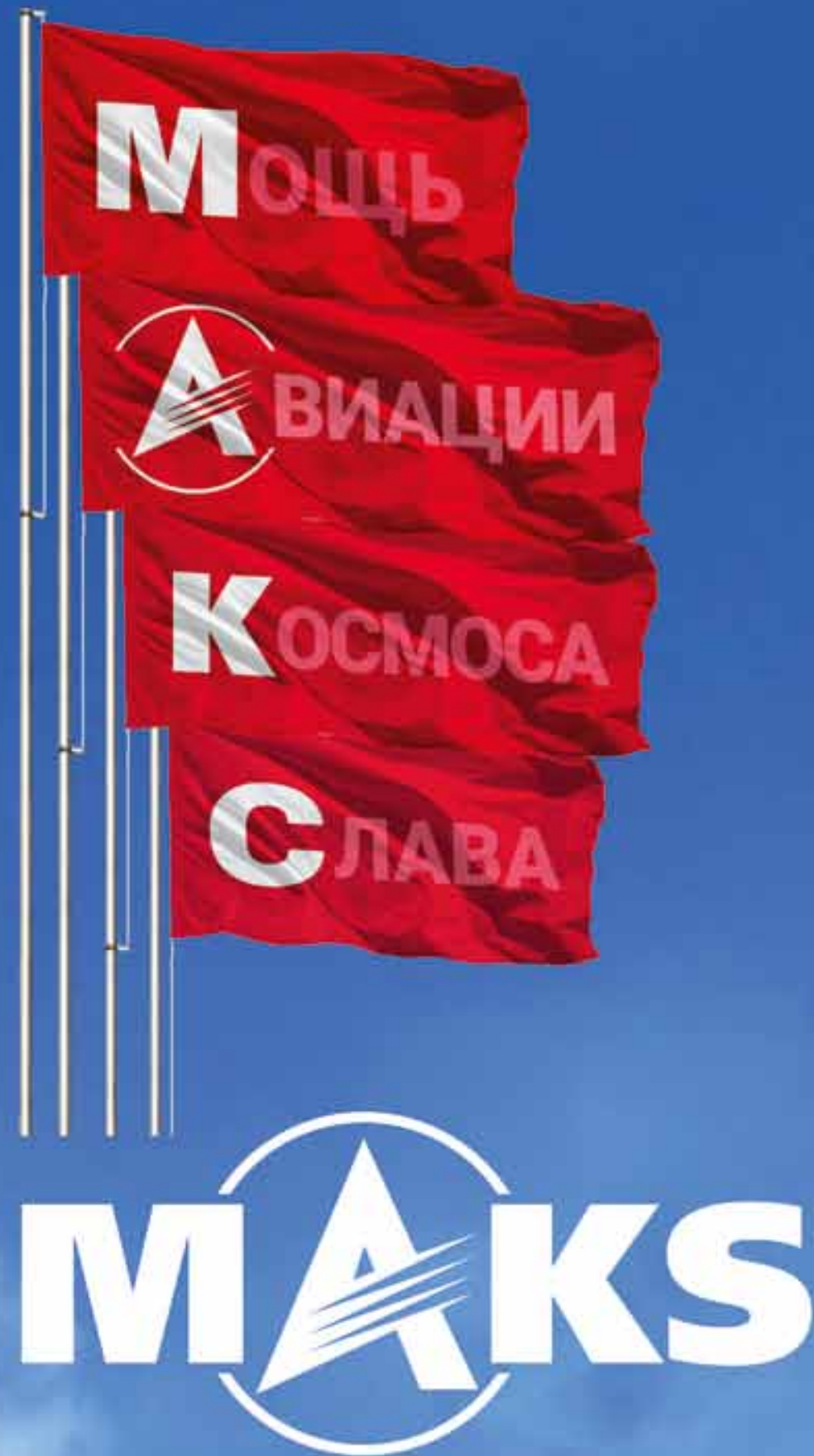

Opraнизаторы

\begin{abstract}
ДЕЛОВАЯ ПРОГРАММА
6 олее 60 конференций, круглых

столов, семинаров и мастер-классов.

Деловая программа «future Hub» -

инновационные научно-технические

разработки молодых ученых
\end{abstract}

\section{ПРЕМЬЕРЫ МАKС-2019}

отечественный лайнер MC 21-300

и гражданские вертолеты Ка-62 и Ми-38

в полете и на земле.

Новинки от Embraer и Pilatus.

\section{СПЕЦИАЛЬНЫЙ ПАВИЛЬОН}

полноразмерный макет российскокитайского широкофюзеляжного дальнемагистрального самолета CR-929

\section{МАСШТАБНАЯЭКСПОЗИЦИЯ БВС}

беспилотники, авионика, двигатели и целевая нагрузка. Демонстрационные полёты БВС и встречи в рамках деловой программы.

\section{БОЛЕЕ 1000 ДЕЛОВЫХ ВСТРЕЧ MATCHMAKING}

поиск деловых партнёров для участников авиасалона: перечень компаний, готовых к встрече, контактные лица, расписание назначенных переговоров.

Подробности на www.aviasalon.com:
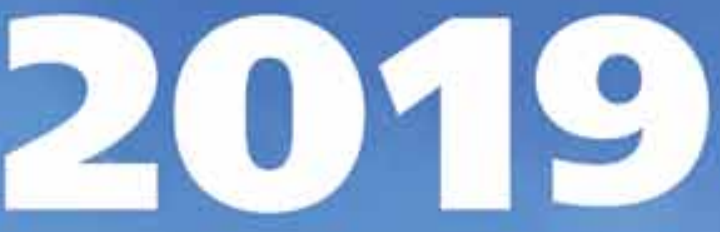

Устроитель

КИТАЙ страна-партнер

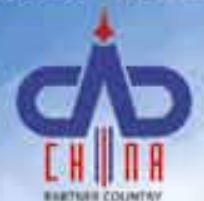

ЖУКОВСКИЙ - 27 АВГУСТА - 1 СЕНТЯБРЯ

Crpatenuecrat Gom naprnep?

(1) пс5
Crpateramecrovid napneopa \% вертолЕтЫ

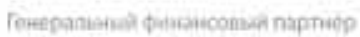
活 НОВИКОМБАНК
Opvasanumad naproẹp

6 рособоронзкспорт

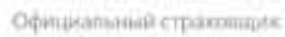
$\sqrt{\mathrm{HE}} \overline{\mathrm{T}}$

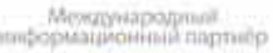

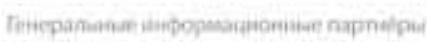

